
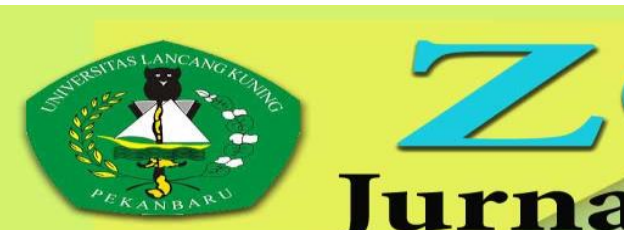

\title{
PENGARUH PEMAHAMAN PRINSIP-PRINSIP GOOD GOVERNANCE, PENGENDALIAN INTERN DAN KOMPETENSI SUMBER DAYA MANUSIA TERHADAP KINERJA INSTANSI PADA PERUM BULOG KANTOR WILAYAH ACEH
}

\author{
Eliana $^{1}$, Nurhayati ${ }^{2}$, Farah Ivana ${ }_{1,2,3,4,5}^{3}$ Indra Kesuma ${ }^{4}$ Cut Siska Mayasar $^{5}$ \\ (Program Studi Akuntansi Sekolah Tinggi Ilmu Ekonomi Sabang Banda Aceh) \\ (Jl. Prada Utama No 15, Banda Aceh 23116 telp. 0651. 7552027)
}

e-mail: ${ }^{1}$ eliana@ @stiesabang.ac.id ${ }^{2}$ nurhayati@ stiesabang.ac.id ${ }^{3}$ Farah@ @tiesabang.ac.id,

Indra@ @ stiesabang.ac.id, ${ }^{5}$ cutsiska@ @stiesabang.ac.id

\begin{abstract}
Abstrak
Riset ini bertujuan buat menganalisis Pengaruh Uraian Prinsip- Prinsip Good Governance, Pengendalian Intern serta Kompetensi Sumber Energi Manusia Terhadap Kinerja Lembaga pada Perum BULOG Kantor Daerah Aceh. Kasus yang mencuat merupakan apakah Uraian Prinsip- Prinsip Good Governance, Pengendalian Intern serta Kompetensi Sumber Energi Manusia Terhadap Kinerja Lembaga pada Perum BULOG Kantor Daerah Aceh.? Dengan demikian riset ini bertujuan buat mengenali besarnya pengaruh Uraian Prinsip- Prinsip Good Governance, Pengendalian Intern serta Kompetensi Sumber Energi Manusia Terhadap Kinerja Lembaga baik secara simultan ataupun secara parsial.

Ilustrasi riset ini diresmikan sebanyak 34 responden. Variabel- variabel Uraian PrinsipPrinsip Good Governance, Pengendalian Intern, Kompetensi Sumber Energi Manusia serta Kinerja Lembaga diukur dengan memakai skala Likert, serta informasi diperoleh dengan menyebarkan kuesioner ke responden. Analisis informasi memakai analisis statistik model korelasi serta regresi berganda dengan dorongan Aplikasi SPSS Tipe 21. Buat menguji tiap item pada tiap variabel sudah dicoba uji validitas serta reabilitas instrument.

Hasil analisis membuktikan kalau secara simultan ada pengaruh antara Uraian PrinsipPrinsip Good Governance, Pengendalian Intern serta Kompetensi Sumber Energi Manusia terhadap Kinerja Lembaga.
\end{abstract}

Kata kunci: Pemahaman Prinsip-Prinsip Good Governance, Pengendalian Intern, Kompetensi Sumber Daya Manusia, Kinerja Instansi.

Abstract
This research aims to analyze the effect of the description of the principles of good governance, internal control and competence of human resources on the performance of institutions at Perum BULOG, Aceh Regional Office. The case that has emerged is what is the Description of the Principles of Good Governance, Internal Control and Competence of Human Resources on Institutional Performance at Perum BULOG Aceh Regional Office.? Thus, this research aims to identify the magnitude of the influence of the Description of the Principles of Good Governance, Internal Control and Competence of Human Resources on Institutional Performance, either simultaneously or partially.

This research illustration was inaugurated by 34 respondents. Variables Description of the Principles of Good Governance, Internal Control, Competence of Human Resources and 
Institutional Performance were measured using a Likert scale, and information was obtained by distributing questionnaires to respondents. Information analysis uses statistical analysis of correlation and multiple regression models with the encouragement of SPSS Type 21 Applications. To test each item on each variable, the validity and reliability of the instrument have been tested.

The results of the analysis prove that there is simultaneously an influence between the Description of the Principles of Good Governance, Internal Control and Competence of Human Resources on Institutional Performance.

Keywords: Understanding the Principles of Good Governance, Internal Control, Human Resource Competence, Agency Performance.

\section{Pendahuluan}

Lahirnya otonomi menjadikan perpindahan sistem pemerintahan yang awal mulanya berwujud sentralisasi jadi desentralisasi. Pada masa otonomi wilayah diberi wewenang serta tanggung jawab dalam mengelola sumber- sumber keuangan buat menjamin kemakmuran rakyatnya[1]. Buat mewujudkan penyelenggaraan pemerintah yang baik hingga pemerintah berupaya mewujudkan pemerintahan yang bersih serta berwibawa dinamakan good governance ialah penerpana prinsip partisipasi, penegakan hukum, transparansi, responsif, orientasi konsensus, kesetaraan, daya guna serta efisiensi, akuntabilitas, serta bervisi strategis[2]. aspek lain yang pula mempengaruhi terhadap kinerja lembaga merupakan pengendalian intern[1]. Pengendalian intern ialah kebijakan- kebijakan, prosedur- prosedur, serta sistem data yang digunakan buat melindungi aset- aset industri dari kerugian ataupun korupsi, serta buat memelihara keakuratan informasi keuangan[1]. Selanjutnya aspek yang pengaruhi kinerja ialah kompetensi sumber energi manusia. Kompetensi SDM mencakup kapasitasnya, ialah keahlian seorang ataupun orang, sesuatu organisasi( kelembagaan), ataupun sesuatu sistem buat melakukan fungsi- fungsi ataupun kewenangannya buat menggapai tujuannya secara efisien serta efektif. Kapasitas wajib dilihat selaku keahlian buat menggapai kinerja, buat menciptakan keluaran( outputs) serta hasil( outcomes)[3].

Perum BULOG Kantor Daerah Aceh ialah salah satu lembaga pangan yang mengurusi tata niaga beras di daerah Aceh. Perum BULOG Kantor Daerah Aceh pula tidak luput dari tanggung jawab dalam pengelolaan dana yang dikucurkan oleh pemerintah tiap tahunnya buat penuhi kebutuhan warga. Tetapi tampaknya, terdapat sebagian pegawai Perum BULOG Kantor Daerah Aceh yang belum melaksanakan tugas cocok dengan yang diharapkan. Bersumber pada pengamatan dini yang dicoba pada Perum BULOG Kantor Daerah Aceh, terdapat sebagian karyawan yang bekerja pada bidang yang tidak cocok dengan latar balik pendidikannya. Dalam proses pencatatan transaksi, pula masih terjalin hambatan dimana masih dicatat secara manual. Perihal tersebut membuat karyawan kurang termotivasi dalam bekerja sehingga terkadang terlambat serta apalagi salah dalam menyusun laporan transaksi keuangan[4]. Tidak hanya itu, kasus sistem akuntansi yang belum mencukupi pula terjalin pada Perum BULOG Kantor Daerah Aceh. Dalam kegiatannya, sistem data akuntansi Perum BULOG Kantor Daerah Aceh belum terintegrasi ataupun belum silih tersambung antara bidang akuntansi dengan bidang- bidang lain. Perihal tersebut menyebabkan dalam proses pencatatan tiap bulannya, bidang akuntansi wajib merekonsiliasi ulang ataupun mengecek ulang pada bidang- bidang lain. Itu dicoba supaya bebas dari perbandingan pencatatan dari bidang- bidang yang lain.

\section{Metode Penelitian}


Penelitian ini dilaksanakan pada Perum BULOG Kantor Wilayah Aceh, Jalan Tengku H.M. Daud Beureueh Banda Aceh. Objek dalam tulisan ini yang ada kaitan dengan kinerja instansi yakni kepuasan stake holder, strategi, proses, kemampuan dan kontribusi. Subjek diambil pegawai yang bekerja di kantor Bulog Aceh. Populasi yang adalah seluruh pegawai di perum Bulog berjumlah 34 orang yang terdiri dari pimpinan, kabid, kasie, resident auditor dan staf. Dikarenakan populasi tidak mencapai 100 orang maka populasi ini dijadikan sampel dan disebut dengan penelitian sensus. Ini sesuai dengan pendapat [5]. Data yang dipergunakan adalah data primer, yang lansung diambil dari objek penelitian [5]. Untuk memperoleh informasi dari responden digunakan kuesioner sebagai media penghubung [5]. Untuk mengetahui pengaruh secara lansung digunakan analisis regresi linier berganda dengan rumus sebagai berikut:

Keterangan :

$$
\mathrm{Y}=\mathrm{a}+\mathrm{b}_{1} \mathrm{X}_{1}+\mathrm{b}_{2} \mathrm{X}_{2}+\mathrm{b}_{3} \mathrm{X}_{3}+\mathrm{e}
$$

$\mathrm{Y}=$ Kinerja institusi

$\mathrm{X} 1=$ Pemahaman prinsip-prinsip good governance

$\mathrm{X} 2=$ Pengendalian intern

$\mathrm{X} 3=$ Kompetensi sumber daya manusia

$\mathrm{b}=$ Parameter regresi/koefisien regresi

$\alpha=$ Intercep/Konstanta

$\mathrm{e}=$ Error

\section{Hasil dan Pembahasan}

Dilihat dari pengembalian kuesioner dapat dijelaskan bahwa dari 34 orang responden laki-laki lebih mendominasi yaitu berjumlah 23 orang atau $67,6 \%$ dibandingkan perempuan Cuma 11 orang atau 32,4\%. Sedangkan usia rata-rata diatas 31-40 tahun yang lebih banyak, untuk Pendidikan terakhir lebih ke sarjana (S-1) yang berjumalh 19 orang dan pegawai dkebanyakan sudah menikah lebih dari $64,7 \%$ atau 22 orang sedangkan masa kerja lebih banyak berada diatas 11-15 tahun yaitu 10 orang atau 29,4\%.

Dari hasil olah data diketahui hasil uji validitas kuesioner mencerminkan bahwa untuk kinerja instansi item pertanyaan semua valid disebabkan berada di atas nilai $\mathrm{r}$ table 34 yakni 0,329.begitu juga dengan variabel prinsip-prinsip GG, Pengendalian Intern dan Kompetensi SDM. Begitu juga dengan pengujian reliabilitas yang menunjukkan hasil yang reliabel berikut ini:

Tabel 1. Hasil Pengujian Reliabilitas

\begin{tabular}{llccc}
\hline No & Variabel & Item & $\begin{array}{l}\text { Cronbach } \\
\text { Alpha }\end{array}$ & Kesimpulan \\
\hline 1. & Kinerja Instansi (Y) & 15 & 0,699 & Handal \\
2. & Prinsip-PrinsiPGood & 8 & 0,640 & Handal \\
& Governance & & & Handal \\
3. & Pengendalian Intern & 9 & 0,613 & Handal \\
4. & Kompetensi SDM & 6 & 0,634 & \\
\hline
\end{tabular}

Hasil dari persepsi responden terhadap variable kinerja instansi dari lima indicator yang digunakan kepuasan stake holder yang mempunyai nilai rata-rata 4,85 artinya jawaban banyak menjawab sangat setuju. Untuk indicator pemahaman prinsip-prinsip GG, di indicator transparansi yang diperoleh jawaban 4,53 yang jawban sangat setuju. Persepsi responden pada variable pengendalian intern, di indicator aktivitas pengendalian yang nilai rata-ratanya 4,26, artinya responden memberikan tanggapan sangat setuju. Begitu juga dengan variable 
kompetensi SDM dari sekian banyak indicator hanya keterampilan yang nilainya 4,47 yang berarti sangat setuju memilih jawaban.

Dari hasil olah data menggunakan statistic regresi linier berganda didapat hasil berikut:

Tabel 2. Pengaruh variable Independen terhadap Dependen

\begin{tabular}{|c|c|c|c|c|c|c|}
\hline \multicolumn{2}{|c|}{$\overline{\text { Model }}$} & \multicolumn{2}{|c|}{$\begin{array}{l}\text { Unstandardized } \\
\text { Coefficients }\end{array}$} & \multirow{2}{*}{$\begin{array}{c}\text { Standardized } \\
\text { Coefficients } \\
\text { Beta }\end{array}$} & \multirow[t]{2}{*}{$\mathrm{t}$} & \multirow[t]{2}{*}{ Sig. } \\
\hline & & $\bar{B}$ & Std. Error & & & \\
\hline \multirow{4}{*}{1} & (Constant) & 18.333 & 7.209 & & 2.543 & .016 \\
\hline & $\begin{array}{l}\text { Pemahaman Prinsip- } \\
\text { Prinsip Good } \\
\text { Governance }\end{array}$ & .477 & .174 & .343 & 2.740 & .010 \\
\hline & Pengendalian Intern & .478 & .162 & .388 & 2.958 & .006 \\
\hline & $\begin{array}{l}\text { Kompetensi Sumber } \\
\text { Daya Manusia }\end{array}$ & .570 & .199 & .347 & 2.860 & .008 \\
\hline
\end{tabular}

Dapat ditulis persamaannya sebagai berikut:

$$
Y=18,333+0,477 X_{1}+0,478 X_{2}+0,570 X_{3}+e
$$

1. Konstanta (a) sebesar 18,333 berarti bahwa jika pemahaman prinsip-prinsip good govermance, pengendalian intern, dan kompetensi sumber daya manusia dianggap nol (tidak ada), maka kinerja instansi pada Perum BULOG Kantor Wilayah Aceh adalah $3,186 \%$.

2. Koefisien regresi pemahaman prinsip-prinsip good govermance 0,477 berarti bahwa setiap kenaikan $100 \%$ pemahaman prinsip-prinsip good govermance akan menaikkan kinerja instansi pada Perum BULOG Kantor Wilayah Aceh sebesar 47,7\% dengan asumsi variabel bebas lainnya konstan.

3. Koefisien regresi pengendalian intern sebesar 0,478 berarti bahwa setiap kenaikan $100 \%$ pengendalian intern akan menaikkan kinerja instansi pada Perum BULOG Kantor Wilayah Aceh sebesar 47,8\% dengan asumsi variabel bebas lainnya konstan.

4. Koefisien regresi kompetensi sumber daya manusia sebesar 0,570 berarti bahwa setiap kenaikan $100 \%$ kompetensi sumber daya manusia akan menaikkan kinerja instansi pada Perum BULOG Kantor Wilayah Aceh sebesar 57,0\% dengan asumsi variabel bebas lainnya konstan.

Pengujian secara simultan untuk mengetahui apakah secara bersama-sama variabel pemahaman prinsip-prinsip good govermance, pengendalian intern dan kompetensi sumber daya manusia mempunyai pengaruh terhadap kinerja instansi, dapat dilihat di table 3:

Tabel 3. Uji Simultan

\begin{tabular}{ll|r|r|r|r|r}
\hline \multicolumn{1}{l|}{ Model } & \multicolumn{1}{c|}{$\begin{array}{l}\text { Sum of } \\
\text { Squares }\end{array}$} & \multicolumn{1}{c|}{ df } & Mean Square & F & \multicolumn{1}{l}{ Sig. } \\
\hline \multirow{2}{*}{1} & Regression & 436.010 & 3 & 145.337 & 15.084 & $.000^{\mathrm{b}}$ \\
\cline { 2 - 7 } & Residual & 289.049 & 30 & 9.635 & & \\
\cline { 2 - 7 } & Total & 725.059 & 33 & & & \\
\hline
\end{tabular}


Berdasarkan table diatas hasil uji simultan nilai $\mathrm{f}_{\text {hitung }}$ sebesar 15,084 dengan nilai signifikansi sebesar 0,000 . Nilai probabilitasnya $(0,000)$ lebih kecil dari 0,05 atau $(0,000<0,05)$ menunjukkan secara simultan variabel pemahaman prinsip-prinsip good govermance $\left(\mathrm{X}_{1}\right)$, pengendalian intern $\left(\mathrm{X}_{2}\right)$, dan kompetensi sumber daya manusia $\left(\mathrm{X}_{3}\right)$ mempunyai pengaruh positif dan signifikan terhadap kinerja instansi (Y) pada Perum BULOG Kantor Wilayah Aceh.

Hasil Uji Secara Parsial (Uji t) dapat dilihat di table 2 yang bermakna

1. Variabel Pemahaman Prinsip-Prinsip Good Govermance $\left(\mathrm{X}_{1}\right)$

Pengaruh pemahaman prinsip-prinsip good govermance $\left(\mathrm{X}_{1}\right)$ terhadap kinerja instansi (Y) dapat dilihat pada Tabel 2 nilai $t_{\text {hitung }}(2,740)$ lebih besar dari $t_{\text {tabel }}(1,695)$ dengan kata lain $t_{\text {hitung }}>t_{\text {tabel }}$ atau $(2,740>1,695)$ dan tingkat signifikansi sebesar 0,010 yang berarti lebih kecil dari standar yang ditetapkan yaitu 0,05 atau $(0,010>0,05)$ terdapat pengaruh positif dan signifikan antara pemahaman prinsip-prinsip good govermance terhadap kinerja instansi pada Perum BULOG Kantor Wilayah Aceh.

2. Variabel Pengendalian Intern $\left(\mathrm{X}_{2}\right)$

Pengaruh pengendalian intern $\left(\mathrm{X}_{2}\right)$ terhadap kinerja instansi $(\mathrm{Y})$ dapat dilihat pada Tabel 2 nilai $t_{\text {hitung }}(2,958)$ lebih besar dari $t_{\text {tabel }}(1,695)$ dengan kata lain $t_{\text {hitung }}>t_{\text {tabel }}$ atau $(2,958>1,695)$ dan tingkat signifikansi sebesar 0,006 yang berarti lebih kecil dari standar yang ditetapkan yaitu 0,05 atau $(0,006>0,05)$. Dari hasil uji signifikan bahwa terdapat pengaruh positif dan signifikan antara pengendalian intern terhadap kinerja instansi pada Perum BULOG Kantor Wilayah Aceh.

3. Variabel Kompetensi Sumber Daya Manusia $\left(\mathrm{X}_{3}\right)$

Pengaruh kompetensi sumber daya manusia $\left(\mathrm{X}_{3}\right)$ terhadap kinerja instansi $(\mathrm{Y})$ dapat dilihat pada Tabel 2 nilai $t_{\text {hitung }}(2,860)$ lebih besar dari $t_{\text {tabel }}(1,695)$ dengan kata lain $t_{\text {hitung }}>t_{\text {tabel }}$ atau $(2,860>1,695)$ maka keputusannya adalah menerima $\mathrm{Ha}_{4}$ dan menolak $\mathrm{Ho}_{4}$, dan tingkat signifikansi sebesar 0,008 yang berarti lebih kecil dari standar yang ditetapkan yaitu 0,05 atau $(0,008>0,05)$. Dari hasil uji signifikan bahwa terdapat pengaruh positif dan signifikan antara kompetensi sumber daya manusia terhadap kinerja instansi pada Perum BULOG Kantor Wilayah Aceh.

Koefisien Korelasi Determinasi $\left(\mathrm{R}^{2}\right)$

Buat mengenali seberapa besar peningkatan sesuatu linier bisa dipaparkan lewat ikatan natara varaibel- variabel( korelasi). Bila segala nilai dari variabel- variabel tersebut bisa penuhi sesuatu persamaan dengan benar, hingga bisa dikatakan ada korelasi yang sempurna dalam model analisis ini.

Tabel 4. Nilai Koefisien Korelasi Determinasi $\left(\mathrm{R}^{2}\right)$

\begin{tabular}{l|r|r|r|r}
\hline \multicolumn{5}{|c}{ Model Summary } \\
\hline Model & R & R Square & $\begin{array}{c}\text { Adjusted R } \\
\text { Square }\end{array}$ & $\begin{array}{l}\text { Std. Error of } \\
\text { the Estimate }\end{array}$ \\
\hline 1 & $.775^{\mathrm{a}}$ & .601 & .561 & 3.104 \\
\hline
\end{tabular}

Dari hasil di atas dapat dilihat bahwa koefisien korelasi $(\mathrm{R}=0,601)$ artinya variabel bebas yaitu pemahaman prinsip-prinsip good govermance, pengendalian intern, dan kompetensi sumber daya manusia mempunyai pengaruh terhadap kinerja instansi pada Perum BULOG Kantor Wilayah Aceh. Sedangkan koefisien determinasi atau R Square $\left(R^{2}\right)$ sebesar 0,601 yang berarti sebesar $60,1 \%$. Variabel bebas mampu mempengaruhi variabel terikat sebesar $60,1 \%$ sedangkan sisanya $39,9 \%$ dipengaruhi variabel lainnya. Seperti transparansi, komitmen organisasi dan partisipasi masyarakat. 


\section{Rincian Pembahasan}

\section{Pengaruh Uraian Prinsip- Prinsip Good Govermance terhadap Kinerja Instansi}

Bersumber pada hasil pengujian yang sudah disajikan tadinya bisa disimpulkan kalau uraian prinsip- prinsip good govermance mempengaruhi serta signifikan terhadap kinerja lembaga pada Perum BULOG Kantor Daerah Aceh. Dengan demikian terus menjadi baik uraian prinsipprinsip good govermance hingga hendak terus menjadi bertambah pula kinerja lembaga pada Perum BULOG Kantor Daerah Aceh. Hasil riset ini cocok dengan oleh hasil riset yang dicoba oleh[1] dari hasil riset yang dicoba oleh periset tadinya ini menampilkan kalau uraian prinsipprinsip good govermance mempengaruhi positif serta signifikan terhadap kinerja lembaga.

\section{Pengaruh Pengendalian Intern terhadap Kinerja Instansi}

Bersumber pada hasil pengujian hipotesis yang sudah terdapat tadinya bisa disimpulkan kalau pengendalian intern mempengaruhi serta signifikan terhadap kinerja lembaga pada Perum BULOG Kantor Daerah Aceh. terus menjadi besar tingkatan pengendalian intern hingga hendak tingkatkan kinerja lembaga pada Perum BULOG Kantor Daerah Aceh. Hasil riset ini cocok dengan oleh hasil riset yang dicoba oleh[6] dari hasil riset yang dicoba oleh periset tadinya ini menampilkan kalau pengendalian intern mempengaruhi positif serta signifikan terhadap kinerja lembaga.

\section{Pengaruh Kompetensi Sumber Energi Manusia terhadap Kinerja Instansi}

Bersumber pada hasil pengujian tadinya bisa disimpulkan kalau kompetensi sumber energi manusia mempengaruhi positif serta signifikan terhadap kinerja lembaga pada Perum BULOG Kantor Daerah Aceh. Dengan demikian terus menjadi besar tingkatan kompetensi sumber energi manusia hingga hendak tingkatkan kinerja lembaga pada Perum BULOG Kantor Daerah Aceh. Hasil riset ini cocok dengan oleh hasil riset yang dicoba oleh[7] dari hasil riset yang dicoba oleh periset tadinya ini menampilkan kalau kompetensi sumber energi manusia mempengaruhi positif serta signifikan terhadap kinerja lembaga.

\section{Kesimpulan}

1. Prinsip-prinsip good governance, pengendalian intern dan kompetensi sumber daya manusia secara simultan berpengaruh positif dan signifikan terhadap kinerja instansi pada Perum BULOG Kantor Wilayah Aceh

2. Prinsip-prinsip good govermance berpengaruh positif dan signifikan terhadap kinerja instansi pada Perum BULOG Kantor Wilayah Aceh.

3. Pengendalian Intern berpengaruh positif dan signifikan terhadap kinerja instansi pada Perum BULOG Kantor Wilayah Aceh.

4. Kompetensi sumber daya manusia berpengaruh positif dan signifikan terhadap kinerja instansi pada Perum BULOG Kantor Wilayah Aceh

\section{Daftar Pustaka}

[1] Azlina, Nur., Amelia, Ira. (2014). Pengaruh Good Governance dan Pengendalian Intern Terhadap Kinerja Auditor Pemerintah Kabupaten Pelalawan. Jurnal Akuntansi. Universitas Pekanbaru. Vol. 12, No. 2

[2] Efendi, D., Tanti, R.A.U. (2019). Pengaruh Penerapan Good Governance dan Pengendalian Internal Terhadap Kinerja Organisasi Publik dengan Komitmen Organisasi Sebagai Pemoderasi. Jurnal Ilmu dan Riset Akuntansi. Vol 8, No. 2 
[3] Fadhil, Muhammad. (2016). Pengaruh Kompetensi Sumber Daya Manusia Terhadap Kinerja Pegawai pada Balai Latihan Kerja Industri Makassar. Jurnal Perspektif. Vol. 1, No. 1.

[4] Chintya, Irine. (2015). Pengaruh Pemanfaatan Teknologi Informasi dan Sistem Pengendalian Intern Pemerintah Terhadap Kinerja Instansi Pemerintah di Kota Solok. Jurnal Akuntansi. Vol. 3, No. 1.

[5] Arikunto, Suharsimi. (2012). Prosedur Penelitian Suatu Pendekatan Praktik. Jakarta: Rineka Cipta

[6] Nasir, Azwir., Oktari, Ranti. (2011). Pengaruh Pemanfaatan Teknologi Informasi dan Pengendalian Intern Terhadap Kinerja Instansi Pemerintah. Jurnal Fakultas Ekonomi Universitas Riau.

[7] Banusu, Andrea Arneyani., Subarjo, Anang. (2017). Faktor-Faktor Yang Berpengaruh Terhadap Kinerja Instansi Pemerintah Kota Surabaya. Jurnal Ilmu dan Riset Akuntansi. Vol. 6, No. 6

[8] Aswandi, Wahyu. (2018). Pengaruh Kompetensi SDM, Pemanfaatan TeknologiInformasi Akuntansi dan Pengawasan Terhadap Kualitas Laporan Keuangan Sektor Publik. Jurnal Akuntansi. Fakultas Ekonomi. Universitas Negeri Padang. Vol. 6, No. 1.

[9] Sugiyono. (2017). Metode Penelitian Kuantitatif, Kualitatif dan R\&D. Bandung: Alfabeta.

[10] Maryam, Neneng, S. (2016). Mewujudkan Good Governance Melalui Pelayanan Publik. Jurnal Ilmu Politik dan Komunikasi. Vol. 6, No. 1.

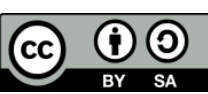

is licensed under a Creative Commons Attribution International (CC BY-SA 4.0) 